\title{
ORGANIZATIONAL CITIZENSHIP BEHAVIOR (OCB) PADA GURU DITINJAU DARI FAKTOR DEMOGRAFI
}

\author{
Mira Ariyani* \\ Desty Zulkarnain** \\ *Fakultas Pendidikan Psikologi, Universitas Negeri Jakarta \\ **Fakultas Pendidikan Psikologi, Universitas Negeri Jakarta
}

DOI: https://doi.org/10.21009/JPPP.062.03

\section{Alamat Korespondensi: \\ mira_ariyani@unj.ac.id}

\begin{abstract}
The objectives of the study were to determine the differences of Organizational Citizenship Behavior $(O C B)$ based on the Extra-role Behavior $(O C B)$ dimensions of the teachers in terms of demographic factors (gender, age, marital status, and employment status). The samples are 138 primary school teachers in districs Duren Sawit, East Jakarta. The study used the Organizational Citizenship Behavior $(O C B)$ scale of the adoption of the Extra-role Behavior (ERB) consisting of 18 items with the reliability alpha $=0.91$. The conclusion is that there is a difference Organizational Citizenship Behavior (OCB) with dimension of Extra-role Behavior (ERB) student in teacher by demography factors (marital status and employment status), dimension of Extra-role Behavior (ERB) team on teacher by demography factor (age, marital status and employment status), and dimension of Extra-role Behavior (ERB) organization on teachers by demographic factors (employment status).
\end{abstract}

Keywords

$O C B, E R B$ dimensions of student, team, organization, demographic factors, gender, age, marital status, employment status, teacher

\section{Pendahuluan}

Saat ini, dinamika organisasi saat bekerja di berbagai negara lebih banyak dilakukan secara tim atau kelompok dibandingkan secara individu. Dalam menjalankan dinamika tersebut, karyawan dituntut untuk memiliki kemampuan berkomunikasi secara terbuka dan jujur, bekerja dengan orang lain, berbagi informasi, mengakui dan menerima perbedaan pendapat, serta lebih mengutamakan tujuan tim diatas tujuan pribadi (Purba $\&$ Seniati, 2004). Semua tuntutan dalam pekerjaan tersebut dapat dijalankan apabila mereka terbiasa untuk saling berhubungan (interaksi) dengan pekerja lain. Interaksi kerja yang dilakukan terus-menerus akan menghasilkan suatu perilaku disebut Perilaku Organisasi. Perilaku
Organisasi (PO) merupakan suatu bidang studi mengamati perilaku individu, kelompok, dan perilaku secara keseluruhan dalam struktur organisasi untuk mendapatkan pengetahuan mengenai aspek yang berkaitan dengan perilaku tersebut sehingga dapat memperbaiki keefektivan organisasi (Mudandar, 2001). Perilaku Organisasi (PO) dapat bersifat positif dan negatif. Salah satu perilaku positif yang dilakukan karyawan adalah Organizational Citizenship Behavior (OCB). OCB didefinisikan sebagai perilaku individu yang bersifat bebas dan sukarela, tidak berkaitan dengan sistem penghargaan dan secara keseluruhan mampu meningkatkan efisiensi dan efektivitas organisasi (Organ, 2006).

Untuk menciptakan OCB, organisasi perlu mengetahui faktor-faktor apa yang dapat mem- 
pengaruhi OCB. Williams dan Anderson (1991) mengatakan bahwa secara kontekstual, kinerja berhubungan dengan watak sehingga dalam operasionalnya, OCB tidak terlepas dari aspek demografi karyawan di tempat kerja (Sarwono \& Soeroso, 2001). Penelitian tersebut didukung oleh Podsakoff, MacKenzie, Paine, dan Bachrach (2000) yang mengatakan bahwa konteks budaya banyak mempengaruhi OCB dimana dalam operasionalnya, OCB tidak dapat dipisahkan dari faktor demografis karyawan di tempat kerja. Faktor demografis terdiri dari jenis kelamin, usia, status pernikahan, dan status kepegawaian (Podsakoff, MacKenzie, Paine,\& Bachrach, 2000).

Faktor demografi Organizational Citizenship Behavior (OCB) pertama yaitu jenis kelamin. Konrad (2000) mengatakan bahwa perilaku organisasi seperti menolong rekan kerja, bersahabat dan bekerjasama dengan orang lain lebih banyak dilakukan wanita dibandingkan pria. Lovel (1999) dalam penelitiannya menemukan perbedaan yang cukup signifikan antara pria dan wanita dalam OCB. Perilaku menolong lebih banyak dilakukan oleh wanita dibandingkan pria (Sahrah, 2012). Morisson (1994) membuktikan bahwa terdapat perbedaan persepsi terhadap OCB berdasarkan jenis kelamin. Wanita menganggap OCB sebagai bagian dari perilaku in-role (Sahrah, 2012). Berdasarkan penelitian-penelitian tersebut menunjukkan bahwa terdapat perbedaan yang cukup signifikan antara pria dan wanita dalam perilaku menolong dan interaksi sosial di tempat kerja.

Faktor demografi Organizational Citizenship Behavior (OCB) kedua yaitu usia. Dalam konteks organisasi, usia pada karyawan dibagi menjadi dua yaitu young worker (pekerja muda) dan older worker (pekerja tua) (Warger \& Rush, 2000). Beberapa penelitian terdahulu telah dilakukan untuk mengetahui pengaruh usia karyawan terhadap OCB dan memperoleh hasil bahwa usia mampu menjadi prediktor signifikan dalam OCB. Geykye \& Haybatollahi (2015) mengatakan bahwa pekerja muda melakukan OCB karena mereka masih memiliki energi dan semangat yang banyak untuk melakukan berbagai kegiatan dalam berorganisasi. Pekerja tua melakukan OCB karena kegiatan mereka di luar tempat kerja lebih sedikit dibandingkan dengan pekerja muda yang aktif dalam berbagai organisasi.

Faktor demografi OCB ketiga yaitu status pernikahan. Penelitian yang dilakukan Rakhroy dan Kaur (2016) menjelaskan bahwa karyawan yang masih lajang lebih berpikiran positif dalam menghadapi permasalahan saat bekerja sehingga mereka tidak suka memprotes atau mengajukan ketidakpuasan terhadap masalah-masalah kecil. Karyawan berstatus lajang memiliki kebebasan dan banyak waktu lebih untuk melakukan kegiatan sukarela diluar pekerjaan formalnya. Penelitian lain yang dilakukan Sarwono dan Soeroso (2001) serta Mahnaz, Mehdi, Jafar, dan Abbloghasem (2013) mengatakan bahwa seseorang yang telah menikah memiliki OCB lebih tinggi dibandingkan dengan lajang. Alasannya karena perubahan status pernikahan dari lajang menjadi menikah dapat meningkatan pengalaman hidup berkeluarga sehingga menumbuhkan sifat toleran, demokratis, menghargai sesama serta menurunkan sifat egois.

Faktor demografi OCB keempat yaitu status kepegawaian. Perbedaan status kepegawaian yang dihadapi karyawan dapat menimbulkan rasa tidak aman khususnya pada karyawan tidak tetap. Hal tersebut terjadi karena sewaktu-waktu perusahaan dapat memutuskan kontrak kerja yang mengakibatkan mereka kehilangan gaji atau pendapatan. Reisel (2010) mengatakan bahwa OCB lebih kuat terkait pada rasa tidak aman karyawan tidak tetap. Penelitian tersebut mengatakan bahwa karyawan tidak tetap atau kontrak melakukan OCB untuk menjaga posisi dan gaji.

OCB merupakan suatu perilaku organisasi yang perlu diterapkan dalam berbagai bidang, salah satunya bidang pendidikan yang dilakukan oleh guru. OCB guru dibagi menjadi tiga yaitu OCB yang dilakukan kepada murid, tim atau rekan kerja, dan organisasi yaitu sekolah (Somech \& Drach-Zahavy, 2000). Guru yang menampilkan OCB merupakan contoh guru yang baik. Jika guru memiliki OCB tinggi, maka secara tidak langsung mereka akan siap melakukan pekerjaan diluar deskripsi pekerjaannya. Srimulyani (2012) dalam penelitiannya mengatakan bahwa jika dalam suatu organisasi memiliki orang-orang dengan tingkat OCB yang tinggi, maka diharapkan organisasi tersebut akan mampu menghadapi tantangan yang 
muncul dari perubahan lingkungan, baik internal maupun eksternal (Humairo \& Mulyana, 2013).

Berdasarkan latar belakang diatas, penulis tertarik untuk mengetahui bagaimana faktor demografis memiliki perbedaan terhadap dimensi OCB pada guru. Dengan demikian, peneliti mengambil judul "Perbedaan Organizational Citizenship Behavior (OCB) pada Guru ditinjau dari faktor demografi (jenis kelamin, usia, status pernikahan, dan status kepegawaian).”

\section{Metode Penelitian}

Metode yang digunakan dalam penelitian ini adalah metode penelitian kuantitatif. Penelitian kuantitatif digunakan untuk meneliti populasi atau sampel tertentu dengan pengumpulan data dengan menggunakan instrumen penelitian dan analisis data yang bertujuan untuk menguji hipotesis yang telah ditetapkan (Sugiyono, 2014). Pendekatan penelitian yang digunakan dalam penelitian ini adalah penelitian komparatif. Penelitian komparatif adalah penelitian yang dimaksudkan untuk mengetahui dan menguji perbedaan dua kelompok atau lebih (Nasehudin dan Gozali, 2012). Penelitian komparatif dalam penelitian ini adalah komparatif deskriptif (descriptive comparative). Penelitian komparatif deskriptif adalah penelitian dengan membandingkan variabel yang sama untuk sampel yang berbeda (Hasan, 2002).

Variabel pada penelitian ini terdiri dari variabel terikat dan bebas. Variabel terikat atau dependent variable adalah variabel yang dipengaruhi atau yang menjadi akibat karena adanya variabel bebas (Sugiyono, 2014). Variabel terikat dalam penelitian ini adalah Organizational Citizenship Behavior (OCB). OCB diukur dengan mengadopsi instrumen Extra-role Behavior (ERB) (Somech \& Drach-Zahavy, 2000). Instrumen terdiri dari 3 dimensi yaitu ERB siswa, ERB tim, dan ERB organisasi. Item yang digunakan berjumlah 18 buah menggunakan skala Likert 7 poin.

Variabel bebas atau independent variable variabel yang mempengaruhi atau yang menjadi sebab perubahan atau timbulnya variabel terikat (Sugiyono, 2014). Variabel bebas dalam pene- litian ini adalah demografi. Demografi adalah karakteristik seseorang yang digunakan untuk mengumpulkan dan mengevaluasi data dalam suatu populasi.

Sampel penelitian sebanyak 138 guru Sekolah Dasar (SD) di Kecamatan Duren Sawit, Jakarta Timur. Penentuan guru SD dilakukan secara random. Teknik sampling yang digunakan pada penelitian ini adalah probability sampling, yaitu teknik pengambilan sampel yang memberikan peluang yang sama bagi setiap anggota populasi untuk dipilih menjadi anggota sampel (Sugiyono, 2014). Probability sampling yang digunakan adalah area sampling (cluster sampling). Teknik sampling daerah digunakan untuk menentukan sampel bila obyek atau sumber data yang akan diteliti sangat luas (Sugiyono, 2014).

Analisis data pada penelitian ini menggunakan model Rasch (Item Response Theory) melalui aplikasi Winstep versi 3.73 dan Classical Test Theory melalui aplikasi Statictical Package of Social Science (SPSS) for Windows Release versi 23.0. Teknik analisis yang digunakan pada penelitian ini yaitu statistika parametrik. Statistika parametrik digunakan untuk menguji parameter populasi melalui statistik atau menguji ukuran populasi melalui data sampel (Sugiyono, 2014). Uji asumsi yang dilakukan berupa uji normalitas dan uji homogenitas, sedangkan uji hipotesis yang dilakukan berupa uji t untuk sampel independen dan Analisis Varians (ANAVA) satu jalur.

\section{Hasil Penelitian dan Diskusi}

Responden dalam penelitian ini berjumlah 138 guru. Responden tersebut dipilih berdasarkan karakteristik sampel penelitian, yaitu guru yang bekerja di lembaga pendidikan formal di Jakarta.

Berdasarkan Tabel 1 diketahui bahwa faktor demografi berupa jenis kelamin terbanyak yaitu perempuan berjumlah 107 orang atau sekitar 77,5\% dari jumlah keseluruhan responden, usia tua berjumlah 76 orang atau sekitar $55,1 \%$ dari jumlah keseluruhan responden, dan berstatus tetap berjumlah berjumlah 85 orang atau sekitar $61,6 \%$ dari jumlah keseluruhan responden. 
Tabel 1. Gambaran Karakteristik Demografi Responden Penelitian

\begin{tabular}{clcc}
\hline Demografi & \multicolumn{1}{c}{ Group } & Jumlah & Persentase \\
\hline \multirow{2}{*}{ Jenis Kelamin } & Laki-laki & 31 & $22,5 \%$ \\
\cline { 2 - 4 } & Perempuan & 107 & $77,5 \%$ \\
\hline \multirow{2}{*}{ Usia } & Muda (<35 tahun) & 62 & $44,9 \%$ \\
\cline { 2 - 4 } & Tua (>35 tahun) & 76 & $55,1 \%$ \\
\hline \multirow{3}{*}{ Status Pernikahan } & Lajang & 46 & $33,3 \%$ \\
\cline { 2 - 4 } & Menikah & 46 & $33,3 \%$ \\
\cline { 2 - 4 } & Bercerai & 46 & $33,3 \%$ \\
\hline \multirow{2}{*}{$\begin{array}{c}\text { Status } \\
\text { Kepegawaian }\end{array}$} & Tetap & 85 & $61,6 \%$ \\
\cline { 2 - 4 } & Tidak Tetap & 53 & $38,4 \%$ \\
\hline
\end{tabular}

Analisis pada penelitian ini dilakukan per dimensi Extra-role Behavior (ERB) yaitu ERB murid, tim, dan organisasi. ERB murid merupakan OCB yang dilakukan terhadap murid.
Berikut merupakan hasil analisis statistik ERB murid dengan uji t untuk sampel independen dan analisis varians satu jalur.

Tabel 2. Uji t untuk Sampel Independen Dimensi Extra-role Behavior (ERB) Murid

\begin{tabular}{lcc}
\multicolumn{1}{c}{ Demografi } & t hit & Nilai $\mathbf{p}$ \\
\hline Jenis Kelamin & 0,906 & 0,367 \\
\hline Usia & $-1,697$ & 0,092 \\
\hline Status Kepegawaian & 3,330 & 0,001 \\
\hline
\end{tabular}

Berdasarkan rumus uji $\mathrm{t}$, jika $\mathrm{t}$ hitung $>\mathrm{t}$ tabel dan nilai $\mathrm{p}<\alpha$ maka hasil penelitian dinyatakan signifikan sehingga Ha diterima dan Ha ditolak. T tabel pada penelitian ini sebesar 1,96. Berdasarkan hasil perhitungan diketahui bahwa terdapat perbedaan Organizational Citizenship Behavior (OCB) dengan dimensi Extra-role Behavior (ERB) murid pada guru ditinjau dari faktor demografi (status kepegawaian).

Tabel 3. Uji Analisis Varian Satu Jalur Dimensi Extra-role Behavior (ERB)

Murid Berdasarkan Status Pernikahan

\begin{tabular}{cc}
\hline ANAVA (F hitung) & $\mathbf{6 , 6 4 8}$ \\
\hline Sig. Between Groups $(\mathrm{p})$ & 0,002 \\
\hline
\end{tabular}

Berdasarkan rumus uji analisis varians, jika $\mathrm{F}$ hitung $>\mathrm{F}$ tabel dan nilai $\mathrm{p}<\alpha$ maka hasil penelitian dinyatakan signifikan sehingga $\mathrm{Ha}$ diterima dan Ha ditolak. F tabel pada penelitian ini sebesar 3,07. Berdasarkan hasil perhitungan diketahui bahwa terdapat perbedaan Organizational Citizenship Behavior (OCB) dengan dimensi Extra-role Behavior (ERB) murid pada guru ditinjau dari faktor demografi (status pernikahan).

Dimensi kedua yaitu ERB tim. Berikut merupakan hasil analisis statistik ERB tim dengan uji t untuk sampel independen dan analisis varians satu jalur. 
Tabel 4. Uji t untuk Sampel Independen Dimensi Extra-role Behavior (ERB) Tim

\begin{tabular}{lcc}
\hline \multicolumn{1}{c}{ Demografi } & t hit & Nilai p \\
\hline Jenis Kelamins & $-0,008$ & 0,994 \\
\hline Usia & $-2,864$ & 0,005 \\
\hline Status Kepegawaian & 2,558 & 0,012 \\
\hline
\end{tabular}

Berdasarkan rumus uji $\mathrm{t}$, jika $\mathrm{t}$ hitung $>\mathrm{t}$ tabel dan nilai $\mathrm{p}<\alpha$ maka hasil penelitian dinyatakan signifikan sehingga Ha diterima dan Ha ditolak. T tabel pada penelitian ini sebesar 1,96. Berdasarkan hasil perhitungan diketahui bahwa terdapat perbedaan Organizational Citizenship Behavior (OCB) dengan dimensi Extra-role Behavior (ERB) murid pada guru ditinjau dari faktor demografi (usia dan status kepegawaian).

Tabel 5. Uji Analisis Varian Satu Jalur Dimensi Extra-role Behavior (ERB) Tim Berdasarkan Status pernikahan

\begin{tabular}{cc}
\hline ANAVA (F hitung) & $\mathbf{3 , 4 3 5}$ \\
\hline Sig. Between Groups (p) & 0,035 \\
\hline
\end{tabular}

Berdasarkan rumus uji analisis varians, jika $F$ hitung $>\mathrm{F}$ tabel dan nilai $\mathrm{p}<\alpha$ maka hasil penelitian dinyatakan signifikan sehingga $\mathrm{Ha}$ diterima dan Ha ditolak. F tabel pada penelitian ini sebesar 3,07. Berdasarkan hasil perhitungan diketahui bahwa terdapat perbedaan Organizational Citizenship Behavior (OCB) dengan dimensi Extra-role Behavior (ERB) tim pada guru ditinjau dari faktor demografi (status pernikahan).

Dimensi ketiga yaitu ERB organisasi. Berikut merupakan hasil analisis statistik ERB organisasi dengan uji t untuk sampel independen dan analisis varians satu jalur.

Tabel 6. Uji t untuk Sampel Independen Dimensi Extra-role Behavior (ERB) Organisasi

\begin{tabular}{lcc}
\hline \multicolumn{1}{c}{ Demografi } & t hit & Nilai $\mathbf{~}$ \\
\hline Jenis Kelamin & 1,204 & 0,231 \\
\hline Usia & $-1,676$ & 0,096 \\
\hline Status Kepegawaian & 2,353 & 0,020 \\
\hline
\end{tabular}

Berdasarkan rumus uji $\mathrm{t}$, jika $\mathrm{t}$ hitung $>\mathrm{t}$ tabel dan nilai $\mathrm{p}<\alpha$ maka hasil penelitian dinyatakan signifikan sehingga Ha diterima dan Ha ditolak. T tabel pada penelitian ini sebesar 1,96. Berdasarkan hasil perhitungan diketahui bahwa terdapat

perbedaan Organizational Citizenship Behavior (OCB) dengan dimensi Extra-role Behavior (ERB) murid pada guru ditinjau dari faktor demografi (status kepegawaian).

Tabel 7. Uji Analisis Varian Satu Jalur Dimensi Extra-role Behavior (ERB) Organisasi Berdasarkan Status Pernikahan

\begin{tabular}{cc}
\hline ANAVA (F hitung) & $\mathbf{2 , 0 1 6}$ \\
\hline Sig. Between Groups $(\mathrm{p})$ & 0,137 \\
\hline
\end{tabular}

Berdasarkan rumus uji analisis varians, jika $F$ hitung $>\mathrm{F}$ tabel dan nilai $\mathrm{p}<\alpha$ maka hasil penelitian dinyatakan signifikan sehingga $\mathrm{Ha}$ diterima dan Ha ditolak. F tabel pada penelitian ini sebesar 3,07. Berdasarkan hasil perhitungan diketahui bahwa tidak terdapat perbedaan Organizational Citizenship Behavior (OCB) dengan dimensi Extra-role Behavior (ERB) tim pada guru ditinjau dari faktor demografi (status pernikahan). 
Setelah melakukan uji hipotesis dapat Behavior $(O C B)$ dan dimensi-dimensi OCB pada diketahui perbedaan Organizational Citizenship masing-masing kelompok status pernikahan.

Tabel 8. Perbedaan Dimensi ERB Murid

\begin{tabular}{|c|c|c|}
\hline \multicolumn{2}{|c|}{ Dimensi ERB Murid } & \multirow{2}{*}{$\begin{array}{c}\text { ERBM Mean } \\
0,481\end{array}$} \\
\hline Statuc Kenergwoion & Tetap & \\
\hline status Nepegawarail & Tidak tetap & 0,114 \\
\hline \multirow{3}{*}{ Status Pernikahan } & Belum Menikah & 0,13 \\
\hline & Menikah & 0,60 \\
\hline & Bercerai & 0,30 \\
\hline
\end{tabular}

Tabel 9. Perbedaan Dimensi ERB Tim

\begin{tabular}{ccc}
\hline \multicolumn{2}{c}{ Dimensi ERB } & ERBT Mean \\
\hline \multirow{2}{*}{ Usia } & Muda & $-0,013$ \\
\cline { 2 - 3 } & Tua & 0,365 \\
\hline \multirow{3}{*}{ Status Pernikahan } & Belum menikah & $-0,04$ \\
\cline { 2 - 3 } & Menikah & 0,33 \\
\cline { 2 - 3 } & Bercerai & 0,31 \\
\hline \multirow{2}{*}{ Status Kepegawaian } & Tetap & 0,327 \\
\cline { 2 - 3 } & Tidak Tetap & $-0,019$ \\
\hline
\end{tabular}

Tabel 10. Perbedaan Dimensi ERB Organisasi

\begin{tabular}{ccc}
\hline \multicolumn{2}{c}{ Dimensi ERBO } & ERBO Mean \\
\hline \multirow{2}{*}{ Status Kepegawaian } & Tetap & 0,327 \\
\cline { 2 - 3 } & Tidak Tetap & $-0,019$ \\
\hline
\end{tabular}

\section{a. Dimensi Extra-role Behavior (ERB) Murid}

Dimensi Extra-role Behavior (ERB) murid mencakup perilaku sukarela yang ditujukan kepada murid. Berdasarkan hasil uji hipotesis melalui perhitungan statistika parametrik menggunakan uji t untuk sampel independen dan Analisis Varians (ANAVA) satu jalur, dapat diketahui bahwa dari empat faktor demografi (jenis kelamin, usia, status pernikahan, dan status kepegawaian), dua faktor demografi berupa status pernikahan dan status kepegawaian menunjukkan adanya perbedaan. Hal tersebut dapat dilihat dari nilai $t$ atau $F$ hitung $>t$ atau $F$ tabel dan nilai $p<$ nilai $\alpha$. Berdasarkan kedua hal tersebut menunjukkan bahwa Ho ditolak dan Ha diterima, artinya terdapat perbedaan Organizational Citizenship Behavior (OCB) dengan dimensi ERB murid pada guru ditinjau dari faktor demografi (status pernikahan dan status kepegawaian).

Pada penelitian ini dapat diketahui perbedaan Organizational Citizenship Behavior (OCB) dengan dimensi ERB murid pada guru berdasarkan setiap kelompok demografi (status pernikahan dan status kepegawaian) dengan melihat nilai mean skor keseluruhan pada masing-masing demografi. Faktor demografi (status pernikahan) memperoleh skor sebesar 0,13 (lajang), menikah memperoleh skor sebesar 0,60, dan bercerai memperoleh skor sebesar 0,30. Faktor demografi (status kepegawaian) memperoleh skor 0,481 (tetap) dan tidak tetap memperoleh skor sebesar 0,114 . Berdasarkan skor tersebut, dapat disimpulkan bahwa ERB murid pada guru menikah dan berstatus pegawai tetap memiliki skor tertinggi 
ERB murid pada guru lajang, dan berstatus pegawai tidak tetap memiliki skor terendah.

Secara keseluruhan ERB murid berbeda. Guru berstatus lajang masih dianggap kurang memiliki pengalaman dengan murid karena saat dirumah mereka masih dianggap sebagai seorang anak dibandingkan dengan guru menikah yang sudah terbiasa untuk mengurus anak saat di rumah. Meskipun guru merupakan orang tua kedua murid disekolah tanpa memandang status pernikahan guru tersebut, guru yang sudah menikah memiliki pengalaman lebih banyak sebagai orang tua dibandingkan dengan guru lajang sehingga OCB ke murid lebih banyak dilakukan oleh guru menikah. Guru tidak tetap memiliki OCB ke murid lebih rendah karena waktu kebersamaaan mereka bersama murid lebih sedikit dibandingkan dengan guru tetap yang memiliki waktu kerja lebih lama.

\section{b. Dimensi Extra-role Behavior (ERB) Tim}

Dimensi Extra-role Behavior (ERB) tim mencakup perilaku sukarela yang ditujukan kepada tim atau rekan kerja. Berdasarkan hasil uji hipotesis melalui perhitungan statistika parametrik menggunakan uji t untuk sampel independen dan Analisis Varians (ANAVA) satu jalur, dapat diketahui bahwa dari empat faktor demografi (jenis kelamin, usia, status pernikahan, dan status kepegawaian), tiga faktor demografi berupa usia, status pernikahan dan status kepegawaian menunjukkan adanya perbedaan. Hal tersebut dapat dilihat dari nilai $\mathrm{t}$ atau $\mathrm{F}$ hitung $>\mathrm{t}$ atau $\mathrm{F}$ tabel dan nilai $\mathrm{p}<$ nilai $\alpha$. Berdasarkan kedua hal tersebut menunjukkan bahwa Ho ditolak dan $\mathrm{Ha}$ diterima, artinya terdapat perbedaan Organizational Citizenship Behavior (OCB) dengan dimensi ERB tim pada guru ditinjau dari faktor demografi (usia, status pernikahan dan status kepegawaian).

Pada penelitian ini dapat diketahui perbedaan Organizational Citizenship Behavior (OCB) dengan dimensi ERB tim pada guru berdasarkan setiap kelompok demografi (usia, status pernikahan dan status kepegawaian) dengan melihat nilai mean skor keseluruhan pada masing-masing demografi. Faktor demografi (usia) memperoleh skor sebesar -0,013 dan usia tua memperoleh skor sebesar 0,365. Faktor demografi (status pernikahan) memperoleh skor sebesar -0,04 (lajang), menikah memperoleh skor sebesar 0,33, dan bercerai memperoleh skor sebesar 0,31. Faktor demografi (status kepegawaian) memperoleh skor 0,327 (tetap) dan tidak tetap memperoleh skor sebesar -0,019. Berdasarkan skor tersebut, dapat disimpulkan bahwa dimensi ERB tim pada guru usia tua, menikah dan berstatus pegawai tetap memiliki skor tertinggi dan dimensi ERB tim pada guru usia muda, lajang, dan berstatus pegawai tidak tetap memiliki skor terendah.

Berdasarkan hasil secara keseluruhan dimensi ini memiliki perbedaan. Individu berusia tua, menikah, dan berstatus pegawai tetap memiliki pengalaman berorganisasi lebih banyak sehingga menurunkan sifat egois, mendengarkan pendapat orang lain serta mau bekerjasama dengan orang lain. Guru berusia tua, menikah dan tetap lebih sukarela untuk membantu rekan kerjanya karena mereka sadar bahwa hidup tidak hanya untuk memenuhi kebutuhan diri sendiri namun juga harus memenuhi kebutuhan orang lain.

\section{c. Dimensi Extra-role Behavior (ERB) Organisasi}

Pada dimensi Extra-role Behavior (ERB) organisasi mencakup perilaku sukarela yang ditujukan kepada organisasi secara keseluruhan. Berdasarkan hasil uji hipotesis melalui perhitungan statistika parametrik menggunakan uji $\mathrm{t}$ untuk sampel independen dan Analisis Varians (ANAVA) satu jalur, dapat diketahui bahwa dari empat faktor demografi (jenis kelamin, usia, status pernikahan, dan status kepegawaian), hanya satu faktor demografi berupa status kepegawaian yang menunjukkan adanya perbedaan. Hal tersebut dapat dilihat dari nilai $\mathrm{t}$ atau $\mathrm{F}$ hitung $>\mathrm{t}$ atau $\mathrm{F}$ tabel dan nilai $\mathrm{p}<$ nilai $\alpha$. Berdasarkan kedua hal tersebut menunjukkan bahwa Ho ditolak dan Ha diterima, artinya terdapat perbedaan Organizational Citizenship Behavior (OCB) dengan dimensi ERB organisasi pada guru ditinjau dari faktor demografi (status kepegawaian).

Pada penelitian ini dapat diketahui perbedaan Organizational Citizenship Behavior (OCB) dengan dimensi ERB organisasi pada guru berdasarkan setiap kelompok demografi (status kepegawaian) dengan melihat nilai mean skor keseluruhan pada masing-masing demografi. Faktor demografi (status kepegawaian) memper- 
oleh skor 0,247 (tetap) dan tidak tetap memperoleh skor sebesar -0,118. Berdasarkan skor tersebut, dapat disimpulkan bahwa dimensi ERB organisasi pada guru tetap memiliki skor tertinggi dan dimensi ERB organisasi pada guru tidak tetap memiliki skor terendah.

Berdasarkan penelitian tesebut, guru tetap memiliki OCB lebih tinggi dibandingkan dengan guru tidak tetap. Guru tetap memiliki jam kerja lebih lama dibandingkan dengan guru tidak tetap sehingga waktu mereka di sekolah lebih lama. Waktu kerja yang lebih lama tersebut membuat guru memiliki lebih banyak waktu untuk melakukan OCB dibandingkan dengan guru tidak tetap yang bisa keluar sekolah saat tidak ada jam mengajar.

\section{Kesimpulan}

Organizational Citizenship Behavior (OCB) merupakan suatu perilaku sukarela diluar deskripsi pekerjaan formal dan tidak mendapatkan reward namun secara keseluruhan dapat meningkatkan keefektivan dalam organisasi. OCB khususnya dalam konteks pendidikan dialami oleh guru. Guru melakukan OCB kepada murid, tim atau rekan sesama guru, serta sekolah sebagai organisasi. OCB yang dilakukan guru berupa perilaku sukarela melebihi persyaratan peran, membantu murid dan guru lain, mencegah terjadinya masalah, dan berpartisipasi dalam berbagai kegiatan organisasi.

Berdasarkan hasil pengujian hipotesis secara statistik pada masing-masing dimensi dapat disimpulkan sebagai berikut:

1. Terdapat perbedaan Organizational Citizenship Behavior (OCB) dengan dimensi Extrarole Behavior (ERB) murid pada guru ditinjau dari faktor demografi (status pernikahan dan status kepegawaian). Guru menikah dan berstatus pegawai tetap memiliki ERB murid paling tinggi.

2. Tidak terdapat perbedaan Organizational Citizenship Behavior (OCB) dengan dimensi Extra-role Behavior (ERB) murid pada guru ditinjau dari faktor demografi (jenis kelamin dan usia).

3. Terdapat perbedaan Organizational Citizenship Behavior (OCB) dengan dimensi Extrarole Behavior (ERB) tim pada guru ditinjau dari faktor demografi (usia, status pernikahan dan status kepegawaian). Guru berusia tua, menikah dan berstatus pegawai tetap memiliki ERB tim paling tinggi.

4. Tidak terdapat perbedaan Organizational Citizenship Behavior (OCB) dengan dimensi Extra-role Behavior (ERB) tim pada guru ditinjau dari faktor demografi (jenis kelamin).

5. Terdapat perbedaan Organizational Citizenship Behavior (OCB) dengan dimensi Extrarole Behavior (ERB) organisasi pada guru ditinjau dari faktor demografi (status kepegawaian). Guru berstatus pegawai tetap memiliki ERB organisasi paling tinggi.

6. Tidak terdapat perbedaan Organizational Citizenship Behavior (OCB) dengan dimensi Extra-role Behavior (ERB) organisasi pada guru ditinjau dari faktor demografi (jenis kelamin, usia, dan status pernikahan).

\section{Daftar Pustaka}

Humairo, H.D., \& Mulyana, O.P. (2013). Perbedaan organizational citizenship behavior (ocb) pada guru sekolah menengah kejuruan (smk) ditinjau dari status sekolah. Character, 2(2), 1-7.

Mahnaz, M. A., Mehdi, M., Jafar, K. M.,\& Abbolghasem, P. (2013). The effect of demographic characteristics on organizational citizenship behavior in the selected teaching hospitals in Tehran. African Journal of Business Management, 7(34), 3324-3331.

Munandar, A. S. (2001). Psikologi Industri dan Organisasi. Depok: Universitas Indonesia.

Organ, D.W., Podsakoff, P.M.,\& Mackenzie, S.B. (2006). Organizational Citizenship Behavior: It's Nature, Antecedents, and Consequences. California: Sage Publications, Inc.

Podsakoff, P., MacKenzie, S., Paine, J.,\& Bachrach, D. (2000). Organizational citizenship

behaviors: a critical review of the theoetical and emperical literature and sugestions for future research. Journal of Management, 26(3), 513-563. 
Purba, D. L., \& Seniati, A. N. L. (2004). Pengaruh kepribadian dan komitmen organisasi terhadap organizational citizenzhip behavior. Makara Sosial Humaniora, 8(3), 105-111.

Rakhroy, G., \& Kaur, P. (2016). Personal characteristics and empowerment: antecedents of organizational citizenship behavior. IRACST - International Journal of Commerce, Business and Management (IJCBM), 5(3), 1-8.
Sarwono, S. S.,\& Soeroso, A. (2001). Determinasi demografi terhadap perilaku karitatif keorganisasian. Jurnal Siasat Bisnis, 1(6), 21-37.

Somech, A., \& Drach-Zahavy, A. (2000). Understanding extra-role behavior in schools: the relationships between job satisfaction, sense of efficacy, and teachers' extra-role behavior. Teachingand Teacher Education, 16, 649-659.

Sugiyono. (2014). Metode Penelitian Kuantitatif, Kualitatif, dan $R \& D$. Bandung: Alfabeta. 